\title{
Monitoring the Chemical and Textural Changes During Ripening of Iranian White Cheese Made with Different Concentrations of Starter
}

\author{
A. Khosrowshahi, ${ }^{\star}$ A. Madadlou, ${ }^{1 *}$ M. Ebrahim zadeh Mousavi, $†$ and Z. Emam-Djomeh $\dagger$ \\ *Urmia University, Food Science \& Engineering, Urmia, Iran \\ †Tehran University, Food Science \& Engineering, Karadj, Iran
}

\begin{abstract}
The effect of the concentration of starter inoculated to milk on the composition, free tyrosine-tryptophan content, microstructure, opacity, and fracture stress of Iranian White cheese (IWC) was studied during $50 \mathrm{~d}$ of ripening in brine. Three treatments of cheese were made using 1-fold (IWC1S), 2-fold (IWC2S), and 4-fold (IWC4S) concentrations of a direct-to-vat mesophilic mixed culture containing Lactococcus lactis ssp. cremoris and Lactococcus lactis ssp. lactis as starter. As ripening progressed, moisture and protein contents of the treatments continuously decreased, whereas their total ash, salt, and salt in moisture contents increased. Fat content and $\mathrm{pH}$ of cheeses remained stable during ripening. The $\mathrm{pH}$ of cheese milk at the time of renneting, which decreased by increasing the concentration of starter (6.57, 6.49, and 6.29 for IWC1S, IWC2S, and IWC4S, respectively), significantly affected most of the chemical characteristics and opacity of cheese. Lower $\mathrm{pH}$ values at renneting decreased moisture and ash contents, whereas cheese protein content increased. The concentration of free tyrosine-tryptophan in curd increased at first $29 \mathrm{~d}$ but decreased between $d 29$ and 49 of aging. The changes observed in cheese whiteness followed the changes in moisture content of the treatments. As the concentration of starter inoculated to milk increased, the value of fracture stress at a given ripening time significantly decreased, leading to a less resistant body against applied stress. A similar trend was also observed for fracture strain during cheese ripening. The micrographs taken by scanning electron microscopy provided a meaningful explanation for decrease in the value of fracture stress. As the cheese ripening progressed or the concentration of starter increased, the surface area occupied by the protein fraction in cheese microstructure decreased, leading the way to lower the force-bearing component in cheese texture.
\end{abstract}

Key words: Iranian White cheese, microstructure, rheology, starter culture

Received December 10, 2005.

Accepted March 29, 2006.

${ }^{1}$ Corresponding author: ashkan.madadlou@gmail.com

\section{INTRODUCTION}

The use of starter cultures containing lactic acid bacteria is an essential requirement in the manufacture of most cheeses (Cogan and Hill, 1993) including Iranian White cheese (IWC). Their major function is to produce lactic acid and, in some cases, flavor compounds (Fox et al., 2000). It is well known that reduction in milk pH due to acidification by starter cells or any other factor is accompanied by micellar demineralization (Banon and Hardy, 1992), which affects cheese curd strength (Cogan and Hill, 1993).

The basic composition and structure of cheeses are determined by the manufacturing operations like $\mathrm{pH}$ at renneting, but it is during ripening that the individual and unique characteristics of each cheese variety develop (Fox et al., 1993). Cheese proteolysis during ripening involves the concerted action of proteolytic enzymes. At the primary phase of ripening, enzymes such as residual chymosin and plasmin (an indigenous proteinase in milk) act on intact casein in the cheese curd. The further breakdown of casein, large peptides, and oligopeptides into small peptides and AA by the proteinases and peptidases of lactic acid bacteria forms the secondary phase of ripening (Mendia et al., 2000; Martínez-Cuesta et al., 2001; Attaie, 2005). These changes contribute in the development of flavor through release of free AA (O'Keeffe et al., 1976; Kondyli et al., 2003) and texture (Fox et al., 1993).

Iranian White cheese is a close-textured brined cheese, resembling Beyaz Peynir (Turkish White cheese) and Feta but differs from Feta in the way it is made. It is, for example, manufactured without dry salting of curd and slime formation on the curd surface before brining, which are essential for the development of the characteristic Feta flavor during ripening (Fox et al., 1993). At the industrial level, the ripening period is 40 to $90 \mathrm{~d}$, but the cheeses made from raw milk in small rural production units may be ripened for 6 to 8 mo (Azarnia et al., 1997). Madadlou et al. (2005) studied the effect of fat content reduction and promoted proteolysis through increasing the concentration of rennet used during cheese manufacture on the textural properties of Iranian White cheese. As fat content in cheese decreased, storage 
modulus $\left(G^{\prime}\right)$, stress at fracture, Young's modulus of elasticity, and work performed up to fracture all increased. However, microstructure of cheese became compact, meltability decreased, and sensory properties of product became undesirable.

The objectives of the present paper were to 1) study the chemical and textural changes that occur in IWC during ripening, and 2) investigate the effect of the different concentrations of culture inoculated to cheese milk on these attributes.

\section{MATERIALS AND METHODS}

\section{Treatments, Cultures, and Rennet}

Three treatments of cheese were made as follows: cheese with 1-fold concentration of starter (IWC1S) made with $0.04 \mathrm{~g}$ of starter $/ \mathrm{kg}$ of milk, cheese with 2fold concentration of starter (IWC2S) made with $0.08 \mathrm{~g}$ of starter $/ \mathrm{kg}$ of milk, and cheese with 4 -fold concentration of starter (IWC4S) made with $0.16 \mathrm{~g}$ of starter $/ \mathrm{kg}$ of milk. Cheeses were manufactured in triplicate, each replicate in $1 \mathrm{~d}$ using $7 \mathrm{~kg}$ of milk for each treatment. One lyophilized direct-to-vat mesophilic mixed culture (R-704, Chr. Hansen's Dairy Cultures, Hoersholm, Denmark) containing Lactococcus lactis ssp. cremoris and Lactococcus lactis ssp. lactis was used as starter. As coagulant, chymosin derived by fermentation of Aspergillus niger var. awamori [standard rennet, Chy-Max, Chr. Hansen Inc.; 183 International Milk Clotting Units (IMCU)/mL (International Dairy Federation, 1997)] was used at a concentration of $4.5 \mathrm{IMCU} / \mathrm{kg}$ of milk. Rennet was diluted 30 -fold with cold water then added to each 7-kg batch of milk.

\section{Cheese-Making Procedure}

Fresh raw milk obtained from Animal Husbandry of Urmia University was batch-pasteurized at $65^{\circ} \mathrm{C}$ for 5 min (Hayaloglu et al., 2002) in a stainless steel container placed in a water bath, cooled to $35^{\circ} \mathrm{C}$, and transported carefully to a cheese vat (model FT20-MkII, Armfield Ltd., Ringwood, Hampshire, UK). The milk was supplemented with $0.15 \mathrm{~g}$ of $\mathrm{CaCl}_{2} / \mathrm{kg}$ of milk and held at $35^{\circ} \mathrm{C}$ for approximately $60 \mathrm{~min}$ after inoculation of culture for starter maturation before the addition of rennet. The curd was cut crossways in cubes of $2 \mathrm{~cm}^{3}$ when firm (after approximately $55 \mathrm{~min}$ ). After being cut, the curd was allowed to settle for 3 to $5 \mathrm{~min}$ and then gently agitated at a gradually increasing rate for $10 \mathrm{~min}$ to avoid fusion of freshly cut curd cubes and to facilitate whey expulsion. This was followed by whey draining and pressing the transferred curd into molds $(14 \times 13 \times 25$ $\mathrm{cm}$ ) for $2.5 \mathrm{~h}$ (under the initial pressure of $0.3 \mathrm{kPa}$, which gradually increased up to approximately $2.9 \mathrm{kPa}$ at the first hour and held constant to the end of pressing) to complete draining. After pressing, the curd was cut in blocks $(4 \times 6 \times 6 \mathrm{~cm})$. The blocks were stored at 23 to $25^{\circ} \mathrm{C}$ for 19 to $20 \mathrm{~h}$, placed in airtight plastic containers, and covered with $13 \%$ brine (brine was pasteurized beforehand at $80^{\circ} \mathrm{C}$ for $10 \mathrm{~min}$, filtered through a clean cloth after rapid cooling, and $\mathrm{pH}$ adjusted to 4.65 by addition of $99 \%$ lactic acid). After sealing, the containers were stored first at 23 to $25^{\circ} \mathrm{C}$ for $24 \mathrm{~h}$ and then refrigerated at 5 to $6^{\circ} \mathrm{C}$ for the ripening period of $50 \mathrm{~d}$.

\section{Chemical Analysis}

Titratable acidity of milk was determined by the Dornic method, and its total solids were determined by drying 8 to $11 \mathrm{~g}$ of milk at $100^{\circ} \mathrm{C}$ for $5 \mathrm{~h}$ (Madadlou et al., 2006). The $\mathrm{pH}$ of milk and cheese samples was measured using a digital $\mathrm{pH}$ meter (microprocessor $\mathrm{pH}$ meter, model pH 537 WTW, Weilheim, Germany). Cheese was analyzed for moisture content by vacuum-oven (AOAC, 1997), salt content by Volhard (James, 1995), and ash content by dry ash method (AOAC, 1997). The fat content of milk and cheese samples was determined by the Gerber method (James, 1995), and their total protein contents were determined by measuring total nitrogen using the Kjeldahl method (AOAC, 1997) and converting it to protein content by multiplying by 6.38 . All chemical measurements were done in triplicate or more. Cheese samples were chemically analyzed at d 2, 29, and 49 of ripening.

Apparent yield was calculated as the weight of cheese before brining (after 19 to $20 \mathrm{~h}$ storage at 23 to $25^{\circ} \mathrm{C}$ ) divided by the weight of the milk used.

\section{Quantification of Free Tyrosine-Tryptophan}

Proteolysis rate in 2-, 29-, and 49-d-old IWC slurries was measured by determing tyrosine-tryptophan concentrations in TCA extracts following the method of Khosrowshahi (1988). Cheese slurries were prepared by mixing 2 parts of the grated cheese sample with 1 part of a sterile $5.2 \%$ solution of sodium chloride at $45^{\circ} \mathrm{C}$. Duplicate 1.0-g samples of slurries were each dispersed in 5.4 $\mathrm{mL}$ of distilled water and placed in a $40^{\circ} \mathrm{C}$ water bath for $5 \mathrm{~min}$. Ten milliliters of $12 \%$ (wt/vol) TCA solution was added to each suspension and allowed to stand for 10 min before being filtered through Whatman No. 2 filter paper. Five milliliters of each TCA extract was added to $10 \mathrm{~mL}$ of a solution containing $15 \%$ sodium carbonate and $2 \%$ sodium hexametaphosphate in Quickfit tubes kept in a $40^{\circ} \mathrm{C}$ water bath. This was followed by the addition of $3 \mathrm{~mL}$ of 3 -time diluted Folinphenol reagent to the tubes. Their contents were shaken thoroughly and were then held in a $40^{\circ} \mathrm{C}$ water bath for 
$5 \mathrm{~min}$ before measuring the absorbance at $650 \mathrm{~nm}$ by a UV-visible spectrophotometer (Ultrospec mode, LKB Biochrom, model 80-2092-26, Pharmacia, Cambridge, UK). To $6 \mathrm{~mL}$ of distilled water, $10 \mathrm{~mL}$ of $12 \%$ (wt/vol) TCA was added and kept at $40^{\circ} \mathrm{C}$ for $5 \mathrm{~min}$, then filtered through Whatman No. 2 filter paper. The procedure was then followed by the addition of $5 \mathrm{~mL}$ of TCA filtrate and then $3 \mathrm{~mL}$ of Folin reagent to $10 \mathrm{~mL}$ of sodium hexametaphosphate solution. This solution was used as a blank. A tyrosine standard curve was prepared using concentrations of $0,5,10$, up to $50 \mu \mathrm{g} / \mathrm{mL}$ in TCA filtrate.

\section{Color Analysis}

The color of 8-, 28-, and 50-d-old samples was quantitatively determined using a Hunter Lab system (model DP9000, Hunter Associates Laboratory Inc., Reston, VA) in which the $\mathrm{L}$ value corresponds to whiteness. Color measurements performed in triplicate for each treatment at different sites.

\section{Microstructure}

Cheese samples were prepared for scanning electron microscopy at d 7, 29, and 49 of ripening following the method of Drake et al. (1996) with modifications. Cheese blocks were cut into approximately 5 to $6 \mathrm{~mm}^{3}$ cubes with a sharp razor and immersed in $2.5 \%$ glutaraldehyde fixative (Merck Science, Darmstadt, Germany) for $3 \mathrm{~h}$. Cubes were then washed 6 times in distilled water (1 min each time), dehydrated in a graded $(40,55,70,85$, 90 , and $96 \%$ ) series of ethanol for $30 \mathrm{~min}$ each, followed by defatting in 3 changes in chloroform (10 min each time). The defatted samples were kept refrigerated and covered with ethanol until they were freeze-fractured in liquid nitrogen (Sipahioglu et al., 1999) to approximately $1-\mathrm{mm}$ pieces. These pieces were mounted on aluminum stubs by silver paint, dried to critical point, and coated with gold for $10 \mathrm{~min}$ in a sputter-coater (type SCD 005, Baltec Inc., Balzers, Switzerland). Samples were viewed in a scanning electron microscope (XL Series, model XL30, Philips, Eindhoven, the Netherlands) operated at $15.0 \mathrm{kV}$. Photomicrographs were recorded at $500 \times$ magnification and edited using ACD Photo Editor software, version 3.1 (Software Spectrum UK Ltd., High Wycombe, UK) for their exposure by maximizing gamma and contrast percentages.

\section{Rheological Analysis}

The simplest fundamental test, uniaxial compression (Tunick, 2000), was performed at d 7, 27, and 49 of ripening using a HTE Universal Testing Machine (SSeries Bench UTM model H5K-S, Hounsfield Test
Equipment Ltd., Redhill, UK) following the method of Tunick (2000) with modifications described by Madadlou et al. (2005) except that cheese blocks were cut into cylinders $24 \mathrm{~mm}$ in diameter and $16 \mathrm{~mm}$ high, and samples were compressed uniaxially with $62.5 \%$ deformation $(10 \mathrm{~mm})$ from the initial height of the sample in one bite. Calculated parameters were stress and Hencky strain at fracture (Madadlou et al., 2005). Each cheese was analyzed in triplicate.

\section{Statistical Analysis}

The experiment was replicated 3 times in a randomized complete block design, which incorporated the 3 treatments (IWC1S, IWC2S, and IWC4S). The ANOVA was carried out using the PROC GLM procedure of SAS statistical software package (Version 8.2, SAS Institute Inc., Cary, NC) to determine the effects of treatment of all variables. Duncan's multiple comparison test was used as a guide for pair comparisons of the treatment means. The level of significance was determined at $P$ $<0.05$.

\section{RESULTS AND DISCUSSION}

\section{Chemical Composition}

As expected, increasing the concentration of starter inoculated to milk significantly affected the $\mathrm{pH}$ value at renneting. The higher the initial starter concentration, the lower was the value of $\mathrm{pH}$ at renneting $(6.57,6.49$, and 6.29 for IWC1S, IWC2S, and IWC4S, respectively). Table 1 shows the chemical characteristics of the milk used for cheese manufacture, treatment composition, yield of cheese making, and free tyrosine-tryptophan content as an index of proteolysis in curd. All of the measured attributes for cheese except fat content were altered by changing the starter concentration or by aging, or both, at $5^{\circ} \mathrm{C}$. In agreement with the result obtained for fat content at the present study, Watkinson et al. (2001) reported no change for fat area distribution with $\mathrm{pH}$ and storage time for semihard model cheeses.

As ripening progressed, moisture and protein contents of the treatments continuously decreased, whereas their total ash, salt, and salt in moisture contents increased. When cheese is placed in brine, there is a net movement of $\mathrm{NaCl}$ molecules, as $\mathrm{Na}^{+}$and $\mathrm{Cl}^{-}$, from the brine into the cheese because of the osmotic pressure difference between the cheese moisture and the brine. Consequently, the water in the cheese containing dissolved materials such as acids and minerals (calcium, magnesium, phosphorus, potassium, etc.) diffuses out through the cheese matrix with a flux approximately twice that of $\mathrm{NaCl}$ so as to restore osmotic pressure equilibrium (Guinee and Fox, 1993). The establishment of these dy- 
namic phenomena decreased the moisture content of the treatments and increased their salt content as they ripened. Hayaloglu et al. (2002) related the decrease in protein content of Turkish White cheese (Beyaz peynir) during ripening to diffusion of some proteolysis products from the curd into the brine. In agreement with the findings in this study, Ehsani et al. (1999) reported that the amount of total N and NPN in the brine was increased during ripening of IWC.

Contrary to our results, Azarnia et al. (1997) reported a decrease in $\mathrm{pH}$ during ripening of IWC in brine (10\% $\mathrm{wt} / \mathrm{vol}, \mathrm{pH}=7.4$ ), mainly because of completion of lactose fermentation and the liberation of amino and free fatty acids. The slow solubilization of colloidal calcium phosphate during ripening, which causes a slow increase in $\mathrm{pH}$ (Lucey et al., 2003), may have offset the tendency for a $\mathrm{pH}$ decrease in the present study, with the result that the cheese $\mathrm{pH}$ remained stable.

The value of $\mathrm{pH}$ at renneting significantly influenced the chemical characteristics of the treatments. As the acidification rate enhanced by increasing the concentration of inoculated starter to milk, the ash content of the treatments decreased, whereas their protein content increased. These trends were always the same at a given storage time. The decrease in the ash content was due to the solubilization of colloidal calcium phosphate, magnesium, and citrate ions (Le Graët and Gaucheron, 1999) at lower $\mathrm{pH}$ and a concomitant increase in the concentration of soluble calcium in the whey. The whey acts as a vehicle in which the soluble calcium is removed from the curd at whey drainage (Guinee et al., 2002).

Lower values of $\mathrm{pH}$ at renneting reduced the net charge on casein micelles and probably improved the activity of rennet (Guinee et al., 2002), leading to greater protein recovery in the curd. This, therefore, increased the protein content of cheese treatments. In agreement with the result obtained in the present study, Banks et al. (1987) reported that the amount of CP in cheese obtained from normally heat-treated milk $\left(72^{\circ} \mathrm{C}\right.$ for 16 s) acidified to $\mathrm{pH} 5.8$ was higher than that of unacidified milk. As the $\mathrm{pH}$ at renneting decreased, the moisture content of the treatments decreased in the current study. Spangler et al. (1991) also reported that Gouda cheeses made from ultrafiltered milk with $3 \%$ starter had lower moisture than those with $1 \%$ starter. According to those researchers, the treatments with higher starter concentrations probably had increased whey syneresis and therefore lower moisture contents. This occurs because the rate of rearrangements of protein-protein bonds in the casein gels during their formation increases as $\mathrm{pH}$ drops (Watkinson et al., 2001).

Concentration of free tyrosine-tryptophan increased between $\mathrm{d} 2$ and 29, whereas it decreased between $\mathrm{d} 29$ and 49 of aging. Azarnia et al. (1997) reported the same 


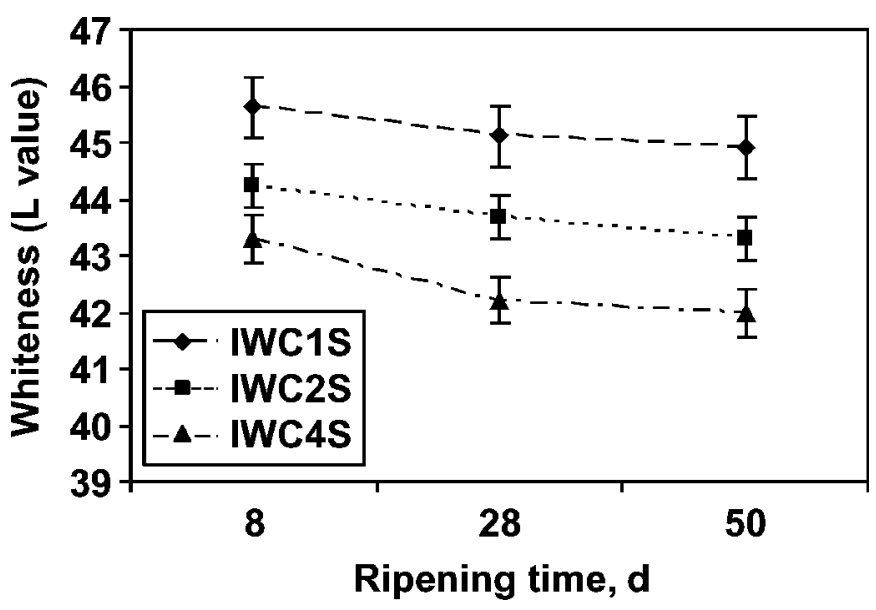

Figure 1. Whiteness changes of Iranian White cheese treatments during ripening. IWC1S, IWC2S, and IWC4S represent Iranian White cheeses made with 1-, 2-, and 4-fold concentrations of starter.

changes for concentration of free AA in IWC curd during the initial $50 \mathrm{~d}$ of aging. They hypothesized that the decrease could be due to decarboxylation, deamination, and transamination reactions. It is, however, our belief that the diffusion of free AA into the brine could be the main reason, as was explained by Caric (1993). As the concentration of starter inoculated to milk increased, the amount of free tyrosine-tryptophan in cheese increased at a given storage time. The strong probability of increased number of starter cells retained at the curd due to the increase in the initial number of cells used to inoculate the milk or decreased $\mathrm{pH}$ at wheying, or both, likely produced more proteinases and peptidases that were excreted into curds and caused more breakdown of casein molecules (Attaie et al., 2005) and larger peptides to smaller peptides and free AA (Dave et al., 2003). The amount of rennet retained in the curd was not measured in the current study; however, it could not take a part in evolution of differences between free tyrosinetryptophan concentrations of the treatments at a given storage time. The portion of rennet lost in the whey during cheese making does not depend on $\mathrm{pH}$ at wheying in the case of microbial rennets (Holmes et al., 1977; Fox, 1989) such as chymosin derived by fermentation of Aspergillus niger var. awamori, which was used in the present study. The lower $\mathrm{pH}$ values of the treatments with higher starter may, however, somewhat improve the activity of retained rennet at the curd (Watkinson et al., 2001), leading to more hydrolysis of casein molecules.

\section{Cheese Opacity}

Figure 1 shows that the progressed ripening and increased concentration of starter significantly decreased the whiteness of IWC. The scattering of light by any system is related to its heterogeneity (Pastorino et al., 2002). In a solid material such as cheese, light penetrates the superficial layers and is scattered by milk fat globules (Lemay et al., 1994) and whey pockets (Paulson et al., 1998). As ripening progressed, whey in serum pockets diffused from the cheese body out into the brine, as seen by moisture loss (Table 1). The surface area occupied by light-scattering centers was therefore decreased. Similarly to our results, Kaya (2002) reported that Gaziantep cheese samples ripened in the weakest brine had the highest moisture content and the highest $\mathrm{L}$ value compared with samples ripened in stronger brines. Color changes as a result of starter concentration were parallel to changes in the moisture content of the treatments at a given ripening time, which resulted in decreased light scattering, and hence, lower L values.

\section{Microstructure and Rheological Analysis}

The changes in microstructural features reflected the biochemical changes in IWC during ripening and also the effect of variations of starter concentration used in this study. The surface area occupied by the protein matrix (white areas in the scanning electron microscope micrographs) decreased visibly during ripening (as seen in panels from top to bottom in Figure 2). Similarly, as the concentration of starter increased, the surface area occupied by the protein matrix decreased at a given storage time (as seen in panels from left to right in Figure 2 ). The hydrolysis of cheese protein network and subsequent diffusion of small peptides and free AA to the surrounding brine may account for the microstructural changes that were observed during ripening and enhanced by increasing the concentration of starter. The protein matrix of the IWC4S treatment occupied the smallest surface area at the end of ripening (Figure 2).

Table 2 reports the values and trends of uniaxial compression parameters for IWC1S, IWC2S, and IWC4S during $49 \mathrm{~d}$ of ripening in brine at $5^{\circ} \mathrm{C}$. The longer the ripening period, the lower were the values of stress and Hencky strain at fracture for a given treatment. Fat and moisture act as the filler in the casein matrix of cheese texture (Madadlou et al., 2005), giving it lubricity and softness. The casein matrix provides the elastic character to cheese texture. The decrease in the volume fraction of force-bearing component (protein) in cheese microstructure during ripening could account for most of the reduced firmness. It is noteworthy that diffusion of salt into cheese during aging changes the strength of the interactions between protein molecules by screening of charged groups. This reduces electrostatic repulsions between protein molecules but also lessens the number of plus-minus interactions between protein molecules 
A

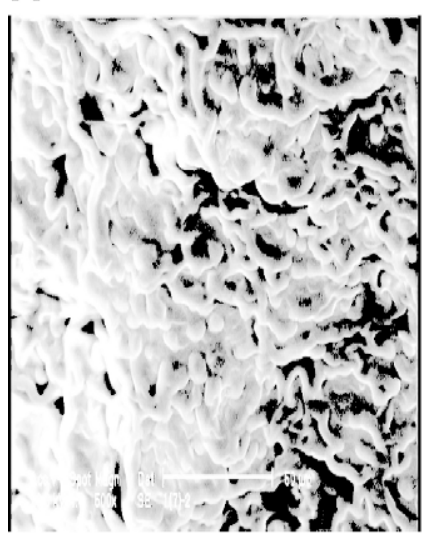

B

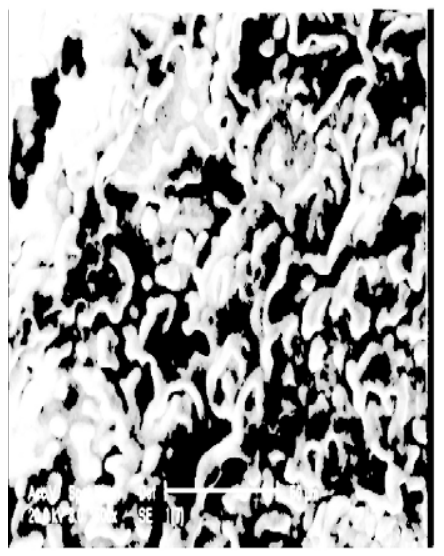

D

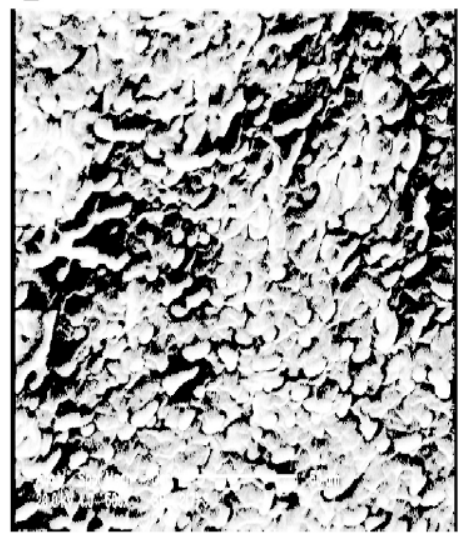

G

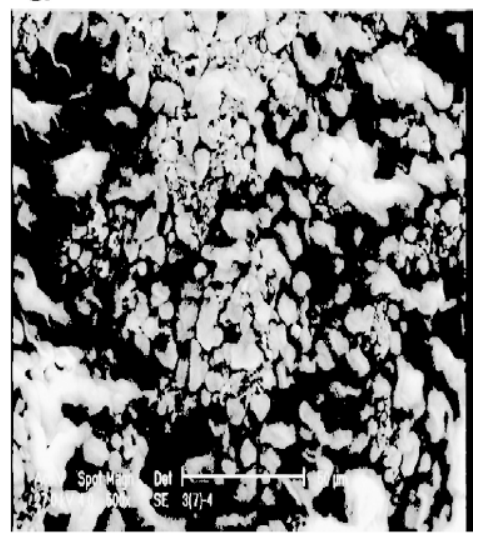

E

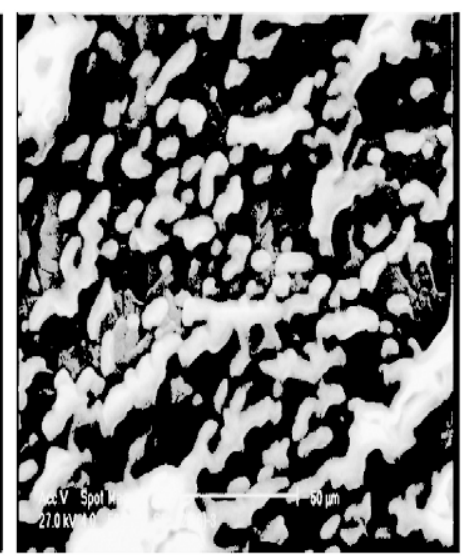

$\mathrm{H}$

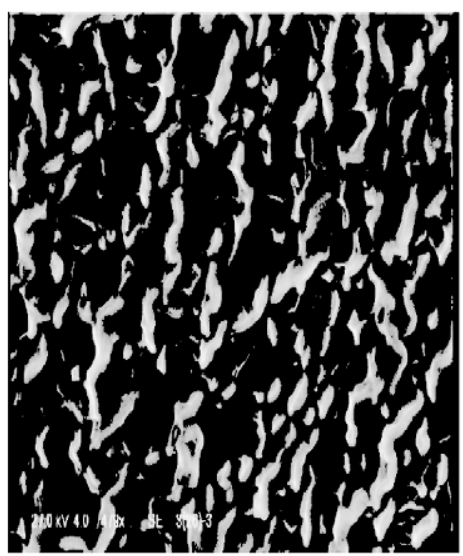

C

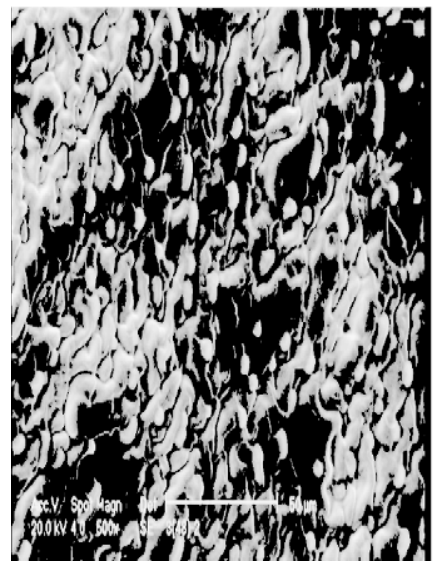

F

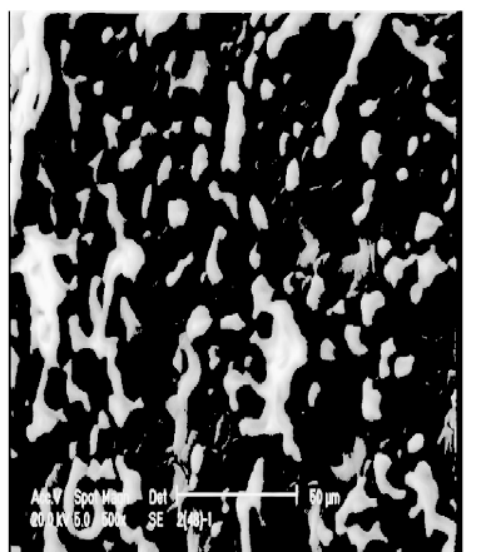

I

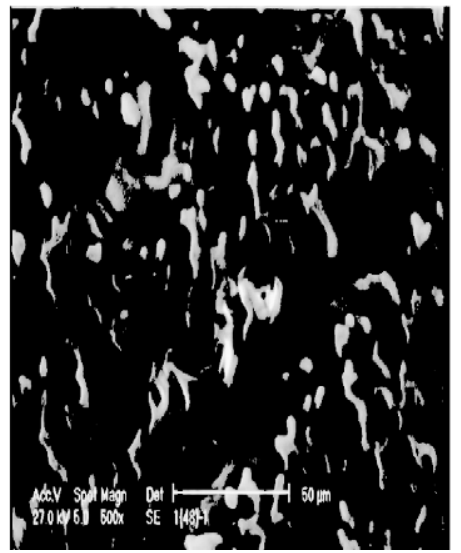

Figure 2. Scanning electron microscope micrographs of Iranian White cheeses (IWC); white areas indicate protein matrix: A) 7-d IWC with 1-fold concentration of starter (IWC1S); B) 27-d IWC1S; C) 49-d IWC1S; D) 7-d IWC with 2-fold concentration of starter (IWC2S); E) 27-d IWC2S; F) 49-d IWC2S; G) 7-d IWC with 4-fold concentration of starter (IWC4S); H) 27-d IWC4S; and I) 49-d IW4S.

(Lucey et al., 2003). The domination of the latter effect likely weakened the structural bonds of the protein matrix of cheese, leading to less resistance against applied stress. According to Kaya (2002), brines with less than $15 \%$ salt could cause weakening of cheese structure. In addition, the slow solubilization of colloidal calcium 


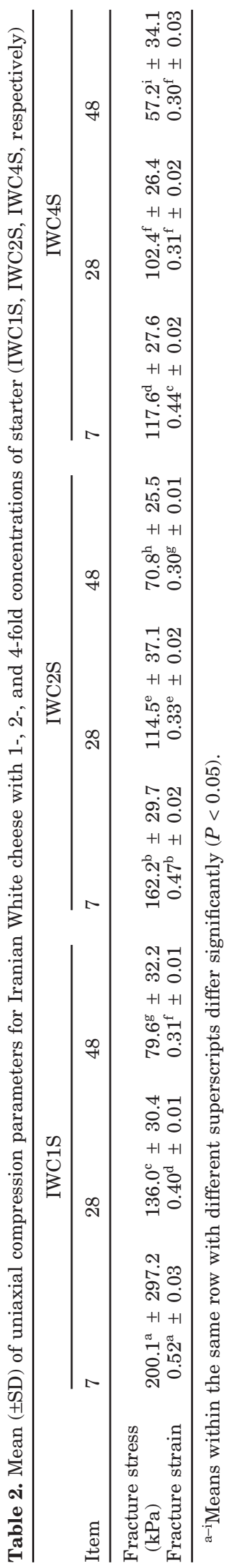

phosphate undoubtedly had a part in softening the treatments during aging (Lucey et al., 2003).

Increasing the concentration of starter inoculated to milk also decreased cheese fracture stress and made the cheese body weaker. It also lowered the value of Hencky strain at fracture and shortened the cheese. The decrease in fracture stress clearly coincided with the decrease in surface area occupied by the protein fraction in cheese microstructure.

In the model of Horne (1998), micellar calcium phosphate is not just regarded as cross-links between casein nanoclusters (Tuinier and de Kruif, 2002), but also as a neutralizing agent, which, being positively charged, binds to negatively charged phosphoserine clusters to reduce the protein charge to the point at which the attractive interactions between hydrophobic regions of the casein can be allowed to dominate. The micelle is not dissociated at temperatures higher than $25^{\circ} \mathrm{C}$ (Banon and Hardy, 1992) by the dissolution out of colloidal calcium phosphate when the $\mathrm{pH}$ is decreased (Dalgleish and Law, 1989; Lucey et al., 2003). It is due to the concurrent neutralization of the phosphoserine charge by the acid (Horne, 1998). The reduction in the amount of calcium associated with casein molecules would, however, increase electrostatic repulsion between caseins (Lucey et al., 2003) and cause a weakening of the structural bonds (Horne, 1998). This probably took a part in the decrease in value of stress at fracture as the $\mathrm{pH}$ at renneting decreased. Watkinson et al. (2001) similarly observed that fracture strain and stress of model cheeses increased as the $\mathrm{pH}$ increased.

\section{CONCLUSIONS}

The concentration of starter inoculated to milk caused variation in the value of $\mathrm{pH}$ at renneting, which in turn affected most of the chemical characteristics and opacity of IWC. The study indicated that texture (rheology and structure), chemical and biochemical composition, and opacity of IWC changed markedly during $50 \mathrm{~d}$ of aging in brine at $5^{\circ} \mathrm{C}$. The changes occurred in microstructure of cheese because of casein hydrolysis, and subsequent diffusion of small peptides and free AA into the brine explained the decrease in cheese firmness due to ripening progress and increased concentration of starter inoculated to milk..

\section{REFERENCES}

AOAC. 1997. Official Methods of Analysis. 3rd rev. of 16th ed. Association of Official Analytical Chemists, Arlington, VA.

Attaie, R. 2005. Effects of aging on rheological and proteolytic properties of goat milk Jack cheese produced according to cow milk procedures. Small Rumin. Res. 57:19-29.

Attaie, R., A. Mora-Gutierrez, and G. R. Newton. 2005. Proteolysis in accelerated ripened goat milk Jack cheese. Milchwissenschaft 60:407-410. 
Azarnia, S., M. R. Ehsani, and S. A. Mirhadi. 1997. Evaluation of the physico-chemical characteristics of the curd during the ripening of Iranian brine cheese. Int. Dairy J. 7:473-478.

Banks, J. M., G. Stewart, D. D. Muir, and I. G. West. 1987. Increasing the yield of Cheddar cheese by the acidification of milk containing heat-denaturated whey protein. Milchwissenschaft 42:212-215.

Banon, S., and J. Hardy. 1992. A colloidal approach of milk acidification by glucono-delta-lactone. J. Dairy Sci. 75:935-941.

Carić, M. 1993. Ripened cheese varieties native to the Balkan countries. Pages 257-276 in Cheese: Chemistry, Physics and Microbiology, Vol. 1, 2nd ed. P. F. Fox, ed. Chapman \& Hall, London, UK.

Cogan, T. M., and C. Hill. 1993. Cheese starter cultures. Pages 193255 in Cheese: Chemistry, Physics and Microbiology. Vol. 1. 2nd ed. P. F. Fox, ed. Chapman \& Hall, London, UK.

Dalgleish, D. G., and A. J. R. Law. 1989. pH-induced dissociation of bovine micelles II. Mineral solubilization and its relation to casein release. J. Dairy Res. 56:727-735.

Dave, R. I., D. J. McMahon, C. J. Oberg, and J. R. Broadbent. 2003. Influence of coagulant level on proteolysis and functionality of Mozzarella cheese made using direct acidification. J. Dairy Sci. 86:114-126.

Drake, M. A., W. Herrett, T. D. Boylston, and B. G. Swanson. 1996. Lecithin improves texture of reduced fat cheeses. J. Food Sci. 61:639-642.

Ehsani, M. R., S. Azarnia, and A. R. Allameh. 1999. The study of the transfer of nitrogen materials, phosphorus, calcium, magnesium, and potassium from the curd into brine during the ripening of Iranian white brined cheese. Iranian J. Agric. Sci. 30:11-17.

Fox, P. F. 1989. Proteolysis during cheese manufacture and ripening. J. Dairy Sci. 72:1379-1400.

Fox, P. F., T. P. Guinee, T. M. Cogan, and P. L. H. McSweeney. 2000. Starter culture. Pages 54-97 in Fundamentals of Cheese Science. Aspen Publishers, Inc., Gaithersburg, MD.

Fox, P. F., J. Law, P. L. H. McSweeney, and J. Wallace. 1993. Biochemistry of cheese ripening. Pages 389-438 in Cheese: Chemistry, Physics and Microbiology. Vol. 1. 2nd ed. P. F. Fox, ed. Chapman \& Hall, London, UK.

Guinee, T. P., E. P. Feeny, M. A. E. Auty, and P. F. Fox. 2002. Effect of $\mathrm{pH}$ and calcium concentration on some textural and functional properties of Mozzarella cheese. J. Dairy Sci. 85:1655-1669.

Guinee, T. P., and P. F. Fox. 1993. Salt in cheese, physical, chemical and biological aspects Pages 257-302 in Cheese: Chemistry, Physics and Microbiology. Vol. 1. 2nd ed. P. F. Fox, ed. Chapman \& Hall, London, UK.

Hayaloglu, A. A., M. Guven, and P. F. Fox. 2002. Microbiological, biochemical and technological properties of Turkish White cheese 'Beyaz Peynir'. Int. Dairy J. 12:635-648.

Holmes, D. G., J. W. Duersch, and C. A. Ernstrom. 1977. Distribution of milk clotting enzymes between curd and whey and their survival during Cheddar cheese making. J. Dairy Sci. 60:862-869.

Horne, D. S. 1998. Casein interactions: Casting light on the black boxes, the structure in dairy products. Int. Dairy J. 8:171-177.

International Dairy Federation (IDF). 1997. Bovine rennets: Determination of total milk clotting activity. Standard 157A. IDF, Brussels, Belgium.
James, C. S. 1995. Analytical chemistry of foods. 1st ed. Chapman \& Hall, Glasgow, UK

Kaya, S. 2002. Effect of salt on hardness and whiteness of Gaziantep cheese during short term brining. J. Food Eng. 52:155-159.

Khosrowshahi, A. 1988. A study of the interaction of heat and concentration in the preparation of milk for cheese making. $\mathrm{PhD}$ thesis. Univ. Reading, Reading, UK.

Kondyli, E., T. Massouras, M. C. Katsiari, and L. P. Voustinas. 2003. Lipolysis and volatile compounds in low-fat Kefalograviera-type cheese made with commercial special starter cultures. Food Contr. 82:203-209

Le Graët, Y., and F. Gaucheron. 1999. pH-induced solubilization of minerals from casein micelles: Influence of casein concentration and ionic strength. J. Dairy Res. 66:215-224.

Lemay, A., P. Paquin, and C. Lacroix. 1994. Influence of microfluidization of milk on Cheddar cheese composition, color, texture, and yield. J. Dairy Sci. 77:2870-2879.

Lucey, J. A., M. E. Johnson, and D. S. Horne. 2003. Perspectives on the basis of the rheology and texture properties of cheese. J. Dairy Sci. 86:2725-2743.

Madadlou, A., A. Khosroshahi, and M. E. Mousavi. 2005. Rheology, microstructure and functionality of low-fat Iranian White cheese made with different concentrations of rennet. J. Dairy Sci. 88:3052-3062.

Madadlou, A., A. Khosroshahi, S. M. Mousavi, and Z. E. Djome. 2006. Microstructure and rheological properties of Iranian White cheese coagulated at various temperatures. J. Dairy Sci. 89:2359-2364.

Martínez-Cuesta, M. C., P. F. de Palencia, T. Requena, and C. Peláez. 2001. Enzymatic ability of Lactobacillus casei subsp. casei IFPL 731 for flavour development in cheese. Int. Dairy J. 11:577-585.

Mendia, C., F. J. Ibaňez, P. Torre, and Y. Barcina. 2000. Effect of pasteurization and use of a native starter culture on proteolysis in a ewe's milk cheese. Food Contr. 11:195-200.

O'Keeffe, R. B., P. F. Fox, and C. Daly. 1976. Contribution of rennet and starter proteases to protelysis in Cheddar cheese. J. Dairy Res. 43:97-107.

Pastorino, A. J., R. I. Dave, C. J. Oberg, and D. J. McMahon. 2002. Temperature effect on structure-opacity relationship of nonfat Mozzarella cheese. J. Dairy Sci. 85:2106-2123.

Paulson, B. M., D. J. McMahon, and C. J. Oberg. 1998. Influence of sodium chloride on appearance, functionality, and protein arrangement in nonfat Mozzarella cheese. J. Dairy Sci. 81:2053-2064.

Sipahioglu, O., V. B. Alvarez, and C. Solano-Lopez. 1999. Structure, physico-chemical and sensory properties of Feta cheese made with tapioca starch and lecithin as fat mimetics. Int. Dairy J. 9:783-789.

Spangler, P. L., L. A. Jensen, C. H. Amundson, N. F. Olson, and C. G. Hill Jr. 1991. Ultrafiltered Gouda cheese: Effects of preacidification, diafiltration, rennet and starter concentration, and time of cut. J. Dairy Sci. 74:2809-2819.

Tuinier, R., and C. G. de Kruif. 2002. Stability of casein micelles in milk. J. Chem. Phys. 117:1290-1295.

Tunick, M. H. 2000. Rheology of dairy foods that gel, stretch, and fracture. J. Dairy Sci. 83:1892-1898.

Watkinson, P., C. Coker, R. Crawford, C. Dodds, K. Johnston, A. McKenna, and N. White. 2001. Effect of cheese $\mathrm{pH}$ and ripening time on model cheese textural properties and proteolysis. Int. Dairy J. 11:455-464. 